\title{
Treatment of lower limb trophic ulcers using hyperbaric oxygenation
}

\author{
Tomasz Kulesza', Tomasz Mitrut ${ }^{1}$, Mariusz Jojczuk', Leszek Jahołkowski' ${ }^{1}$ Adam Nodalski' \\ Andrzej Prystupa ${ }^{2}$ \\ ${ }^{1}$ Department of Trauma Surgery and Emergency Medicine, Medical University, Lublin, Poland \\ ${ }^{2}$ Department of Internal Medicine, Medical University, Lublin, Poland
}

Kulesza T, Mitrut T, Jojczuk M, Jahołkowski L, Nodalski A, Prystupa A. Treatment of lower limb trophic ulcers using hyperbaric oxygenation. J Pre-Clin Clin Res. 2014; 8(1): 44-47.

\begin{abstract}
Lower limb venous ulcers affect approximately 1-1.3\% of the population and constitute the most dangerous and distressing complication related to chronic venous insufficiency. Although the issue of trophic ulcer pathogenesis remains unclear, it is beyond doubt that adequate oxygen delivery to the tissues is the key factor in wound healing. Recent technological advances allow the use of hyperbaric oxygenation in patients with hard-to-heal wounds.

Objective. The aim of this study is to present own results regarding the use of hyperbaric oxygenation in a group of 37 patients with lower limb trophic ulcers of vascular etiology, who were treated in the Clinic of Trauma Surgery and Emergency Medicine in Lublin.

Material and methods. The study involved 37 patients, 22 women and 15 men, aged 42-84 years, treated in the Clinic of Trauma Surgery and Emergency Medicine in Lublin in 2011-2012. The group treated in the Clinic included 30 patients with venous ulcers (the largest group) as well as 3 patients with arterial ulcers and 4 patients with mixed arterial/venous ulcers. Patients were referred for further treatment in the Hyperbaric Centre of the District Hospital in Łęczna. The treatment included 20-30 compression sessions at a pressure of 2.5 ATA $1.6 \mathrm{~kg} / \mathrm{cm}$ in a HiperTech Zyron 12 Multiplace chamber. A single session lasted 90 minutes.

Results. Hyperbaric chamber treatment resulted in complete wound healing in 22 patients (more than 59\%). Partial wound healing (half of the surface area) was achieved in 13 patients (35\%). Lack of wound healing was observed in 2 patients (5\%) with arterial and mixed ulcers.
\end{abstract}

\section{Key words}

trophic ulcers, hyperbaric oxygenation, lower limb

\section{INTRODUCTION}

Venous diseases of the lower limbs, as well as their complications, are a serious medical, social and economic issue. Lower limb ulceration involves the loss of skin and subcutaneous tissue, the development of which is very complex. Despite its prevalence and a number of well-known predisposing factors, the causes and the pathogenesis of this condition are not unambiguously determined. Distal parts of the tibia, as well as its lateral and medial surface, are most prone to ulceration. Lower limb venous ulcers affect approximately $1-1.3 \%$ of the population and constitute the most dangerous and distressing complication related to chronic venous insufficiency $[1,2,3,4,5]$. Extensive epidemiological studies have shown that women are at 3 times higher risk than men $[1,6]$. Many authors note that the costs of treating patients with ulcerations are always high due to several factors, including the chronicity of the disease, a variety of therapeutic agents used at different stages of the disease, the need to train health care providers involved in treating this group of patients, as well as repeated use of modern diagnostic methods $[7,8,9]$.

Non-healing ulcers that last for years considerably affect patients' general condition, their psyche and physical activity

Address for correspondence: Andrzej Prystupa, Department of Internal Medicine, 20-081 Lublin, Poland

e-mail: aprystup@mpl

Received: 2013 June 30; accepted: 2014 April 01 in particular. Large ulcerations result in significant loss of protein, tissue fluid and plasma.

Ulcers are usually treated non-invasive; however, the present methods of treatment aim to eliminate the cause of venous insufficiency via surgical procedures $[1,6,10,11,12]$.

Although the issue of trophic ulcer pathogenesis remains unclear, it is beyond doubt that adequate oxygen delivery to the tissues is the key factor in wound healing $[13,14,15]$. Recent technological advances allow the use of hyperbaric oxygenation in patients with hard-to-heal wounds.

Aim of the study. The aim of this study is to present own results regarding the use of hyperbaric oxygenation in a group of 37 patients with lower limb trophic ulcers of vascular etiology, who were treated in the Clinic of Trauma Surgery and Emergency Medicine in Lublin.

\section{MATERIALS AND METHOD}

The study involved 37 patients, 22 women and 15 men, aged 42-84 years, treated in the Clinic of Trauma Surgery and Emergency Medicine in Lublin in 2011-2012 (Tab. 1). The average period of hospitalization was 8 days. The duration of ulcers ranged from 2 to more than 15 years (Tab. 2).

The majority of patients, i.e. 13, were treated due to lower limb ulcers for a period of 11-15 years.

The group treated in the Clinic included 30 patients with venous ulcers (the largest group) as well as 3 patients with 
Table 1. Age distribution of the study group of patients

\begin{tabular}{lccccc}
\hline Gender/age in years & $42-52$ & $53-63$ & $64-73$ & Over 74 & Total \\
\hline Women & 2 & 4 & 11 & 5 & 22 \\
\hline Men & 1 & 3 & 8 & 3 & 15 \\
\hline Total & 3 & 7 & 19 & 8 & 37 \\
\hline Group \% & $8.1 \%$ & $18.9 \%$ & $51.3 \%$ & $21.6 \%$ & $100 \%$ \\
\hline
\end{tabular}

Table 2. Duration of ulcers in the study group of patients

\begin{tabular}{lccccc}
\hline Disease duration in years & $2-5$ & $6-10$ & $11-15$ & Over 15 & Total \\
\hline Women & 2 & 5 & 10 & 5 & 22 \\
\hline Men & 3 & 6 & 3 & 3 & 15 \\
\hline Total & 5 & 11 & 13 & 8 & 37 \\
\hline Group \% & $13.5 \%$ & $29.7 \%$ & $35.1 \%$ & $21.6 \%$ & $100 \%$ \\
\hline
\end{tabular}

arterial ulcers and 4 patients with mixed arterial/venous ulcers (Tab. 3). Patients were further divided into three groups based on the size of lower limb ulceration (Tab. 4).

Table 3. Type of ulcer based on patient's gender

\begin{tabular}{|c|c|c|c|c|}
\hline Type of ulcer & venous & arterial & mixed & total \\
\hline Women & 17 & 2 & 3 & 22 \\
\hline Men & 13 & 1 & 1 & 15 \\
\hline Total & 30 & 3 & 4 & 37 \\
\hline Group \% & $81.1 \%$ & $8.1 \%$ & $10.8 \%$ & $100 \%$ \\
\hline
\end{tabular}

Table 4. Ulceration surface area in the group of patients

\begin{tabular}{lcccc}
\hline Ulceration area & Up to $50 \mathrm{~cm}^{2}$ & $50 \mathrm{~cm}^{2}-150 \mathrm{~cm}^{2}$ & More than $150 \mathrm{~cm}^{2}$ & Total \\
\hline Women & 2 & 8 & 12 & 22 \\
\hline Men & 1 & 5 & 9 & 15 \\
\hline Total & 3 & 13 & 21 & 37 \\
\hline Group $\%$ & $8.1 \%$ & $35.1 \%$ & $56.7 \%$ & $100 \%$ \\
\hline
\end{tabular}

Ulcers were always located in the distal part of the tibia. The largest group included patients with an ulceration surface area of more than $150 \mathrm{~cm}$. Only one patient out of 37 was not burdened with concomitant diseases (Tab. 5). The remaining patients suffered from diabetes, hypertension, allergies or collagenosis. Five patients had previously experienced lower limb injuries in the form of upper or lower leg fracture. The condition of ulcers is shown in Table 6.

Table 5. Concomitant diseases in the group of patients

\begin{tabular}{lcccccc}
\hline Disease & $\begin{array}{c}\text { Hyper- } \\
\text { tension }\end{array}$ & $\begin{array}{c}\text { Diabetes } \\
\text { Type } 2\end{array}$ & $\begin{array}{c}\text { Collage- } \\
\text { nosis }\end{array}$ & $\begin{array}{c}\text { Allergic reactions } \\
\text { to medications } \\
\text { or dressing } \\
\text { materials }\end{array}$ & Injuries & Total \\
\hline Women & 10 & 6 & 2 & 1 & 1 & 20 \\
\hline Men & 8 & 2 & 1 & 1 & 4 & 12 \\
\hline Total & 18 & 8 & 3 & 2 & 5 & 36 \\
\hline Group \% & $48.6 \%$ & $21.6 \%$ & $8.1 \%$ & $5.4 \%$ & $13.5 \%$ & $100 \%$ \\
\hline
\end{tabular}

In the majority of patients, the ulcers were predominantly covered with a purulent exudate containing necrotic tissue. During their stay at the Clinic, the patients underwent
Table 6. The condition of ulcers based on the presence of necrotic tissue, with an indication for necrectomy.

\begin{tabular}{lcccc}
\hline $\begin{array}{c}\text { Condition of } \\
\text { ulcers }\end{array}$ & $\begin{array}{c}\text { Granulation no } \\
\text { indications for } \\
\text { necrectomy }\end{array}$ & $\begin{array}{c}\text { Indication } \\
\text { for single } \\
\text { necrectomy }\end{array}$ & $\begin{array}{c}\text { Indication } \\
\text { for repeated } \\
\text { necrectomy }\end{array}$ & Total \\
\hline Women & 4 & 12 & 6 & 22 \\
\hline Men & 3 & 10 & 2 & 15 \\
\hline Total & 7 & 22 & 8 & 37 \\
\hline Group $\%$ & $18.9 \%$ & $59.4 \%$ & $21.6 \%$ & $100 \%$ \\
\hline
\end{tabular}

necrectomy procedures, consisting in surgical ulcer debridement. In most patients, the procedure was performed once, whereas 8 patients required the procedure to be repeated several times. Necrectomy procedures were performed in the operating room under intravenous anesthesia. In each case, efforts were made to restore pure granulation tissue.

A total of 36 patients developed infected ulcers. Infection was confirmed in hospitalized patients by performing ulcer swab culture and antibiograms on the first day of hospitalization. The majority of patients developed mixed infections. Single infections occurred in only 6 patients (Tab. 7).

Table 7. Infected ulcers in the study group

\begin{tabular}{lcccc}
\hline Infection & $\begin{array}{c}\text { Single infection (one } \\
\text { type of bacteria) }\end{array}$ & Mixed infection & $\begin{array}{c}\text { No growth in } \\
\text { culture }\end{array}$ & Total \\
\hline Women & 4 & 17 & 1 & 22 \\
\hline Men & 2 & 13 & 0 & 15 \\
\hline Total & 6 & 30 & 1 & 37 \\
\hline Group \% & $16.2 \%$ & $81.1 \%$ & $2.7 \%$ & $100 \%$ \\
\hline
\end{tabular}

Both mixed and single infections were caused by the following strains: Staphylococcus aureus, MRSA and MSSA, Streptococcus pyogenes, Proteus vulgaris, Acinetobacter baumannii, Escherichia coli, Pseudomonas aeruginosa.

Once the preparation of the ulcer for hyperbaric chamber treatment was completed at the Clinic, patients were referred for further treatment in the Hyperbaric Centre of the District Hospital in Łęczna. The treatment included 20-30 compression sessions at a pressure of 2.5 ATA $1.6 \mathrm{~kg} / \mathrm{cm}$ in a HiperTech Zyron 12 Multiplace chamber. A single session lasted 90 minutes. Patients with incomplete ulcer healing following hyperbaric oxygen therapy were re-admitted to the hospital in order to complete the healing process using a meshed split-thickness skin graft.

\section{RESULTS}

Hyperbaric chamber treatment resulted in complete wound healing in 22 patients (more than 59\%). Partial wound healing (half of the surface area) was achieved in 13 patients (35\%). Lack of wound healing was observed in 2 patients (5\%) with arterial and mixed ulcers. These had a surface area of more than $150 \mathrm{~cm}$ and occurred in elderly patients. Furthermore, the duration of these ulcers was also extended, namely over 11 years. Individual results of hyperbaric chamber treatment are shown in Table 8, 9, 10, 11.

Partial wound healing (half of the ulcer surface area) was achieved in 13 patients, who were then readmitted to the 
Table 8. Hyperbaric oxygen treatment results based on the age of the patients

\begin{tabular}{lccc}
\hline $\begin{array}{c}\text { Age/wound } \\
\text { condition }\end{array}$ & Fully healed & $\begin{array}{c}\text { Healing incomplete, } \\
\text { skin graft required }\end{array}$ & Not healed \\
\hline $45-52$ & 3 & 0 & 0 \\
\hline $53-63$ & 5 & 2 & 0 \\
\hline $64-73$ & 11 & 8 & 0 \\
\hline Over 74 & 3 & 3 & 2 \\
\hline Total & 22 & 13 & 2 \\
\hline Group \% & $59.4 \%$ & $35.1 \%$ & $5.4 \%$ \\
\hline
\end{tabular}

Table 9. Ulcer healing based on duration of the disease

\begin{tabular}{lccc}
\hline $\begin{array}{l}\text { Duration in years/ } \\
\text { wound condition }\end{array}$ & Fully healed & $\begin{array}{c}50 \% \text { of the } \\
\text { surface healed }\end{array}$ & Not healed \\
\hline $2-5$ & 5 & 0 & 0 \\
\hline $6-10$ & 10 & 1 & 0 \\
\hline $11-15$ & 5 & 7 & 1 \\
\hline Over 15 & 2 & 5 & 1 \\
\hline Total & 22 & 13 & 2 \\
\hline Group \% & $59.4 \%$ & $35.1 \%$ & $5.4 \%$ \\
\hline
\end{tabular}

Table 10. Ulcer healing based on surface area

\begin{tabular}{lcccc}
\hline Ulcer surface area & Fully healed & $50 \%$ healed & Not healed & Total \\
\hline Up to $50 \mathrm{~cm}^{2}$ & 3 & 0 & 0 & 3 \\
\hline $50 \mathrm{~cm}^{2-} 150 \mathrm{~cm}^{2}$ & 9 & 4 & 0 & 13 \\
\hline More than $150 \mathrm{~cm}^{2}$ & 10 & 9 & 2 & 21 \\
\hline Total & 22 & 13 & 2 & 37 \\
\hline Group $\%$ & $59.4 \%$ & $35.1 \%$ & $5.4 \%$ & $100 \%$ \\
\hline
\end{tabular}

Table 11. Ulcer healing based on type of ulcer

\begin{tabular}{lcccc}
\hline Type of ulcer & Fully healed & About 50\% healed & Not healed & Total \\
\hline Venous & 21 & 9 & 0 & 30 \\
\hline Arterial & 0 & 2 & 1 & 3 \\
\hline Mixed & 1 & 2 & 1 & 4 \\
\hline Total & 22 & 13 & 2 & 37 \\
\hline Group \% & $59.4 \%$ & $35.1 \%$ & $5.4 \%$ & $100 \%$ \\
\hline
\end{tabular}

Clinic and received meshed split-thickness skin grafts, which resulted in full wound healing or $90 \%$ recovery of the affected area. The average time of the stay at the Clinic was 8 days.

Complete healing was most frequently observed in venous ulcers with a surface area of $150 \mathrm{~cm}$, which occurred in the age group of $64-73$ years. The duration of ulcers ranged from 6-10 years.

Patients with healed ulcers were monitored in the Trauma Surgery Clinic in Lublin. Each patient was monitored for a period of 3 months. Each discharged patient with healed ulcers received appropriate instructions regarding limb elevation and pressotherapy $[6,16]$.

\section{DISCUSSION}

The use of hyperbaric oxygenation in the treatment of lower limb trophic ulcers is well established in the recommendations issued by the Undersea and Hyperbaric Medical Society (UHMS) in 1976 and the European Committee for Hyperbaric Medicine (ECHM) in 1989. The use of this therapy in the treatment of chronic wounds is supported by publications [17].

In the case of treating hard-to-heal wounds and ulcers, hypoxia occurs in the tissues surrounding the wound. This is due to microcirculation impairment and the resulting insufficient supply of oxygen to the peripheral wound parts, with the formation of an unfavourable concentration gradient between the periphery and the focal point of the wound. Oxygen pressure may drop to zero in the centre of the wound. The use of hyperbaric oxygen accelerates collagen production and deposition, angiogenesis stimulation, as well as the increase in leukocyte antimicrobial activity. Furthermore, increased oxygen pressure limits endothelial cell damage by inhibiting the ability of neutrophils to adhere to vessel walls, narrowing the microcirculatory vessels within the undamaged areas and improving blood flow in the affected areas. The supply of oxygen to ischemic tissue accelerates healing. In some cases, oxygen therapy allows for a complete healing. In other cases, however, oxygen therapy prepares the patient for further treatment, such as split-thickness skin grafting $[18,19]$.

The presented study support these findings by obtaining very good results in $59 \%$ of patients and satisfactory results in $35 \%$ of patients. The remaining patients suffered from diabetes, hypertension, allergies or collagenosis; 5 patients had previously experienced lower limb injuries in the form of upper or lower leg fracture. The condition of ulcers is shown in Table 6.

Healed ulcers due to hyperbaric oxygen therapy were considered a very good result, whereas the need to cover the prepared site with split-thickness skin graft was considered a satisfactory result.

Concomitant diseases in patients with trophic ulcers often complicate the treatment process. During hyperbaric procedure, an increase of systolic and diastolic blood pressure occurs in patients, which is most likely due to peripheral resistance increase [20]. The presented study included 18 patients with hypertension. Despite reports on increased blood pressure in hyperbaric-treated patients, this method was used successfully for the current study and no increase was observed in blood pressure during compressions [20].

Hyperbaric oxygen therapy significantly reduces wound infections and increases the antibacterial activity of antibiotics, even in the case of osteomyelitis [21, 22, 23]. The majority of patients included in this study had mixed infections. Almost all the wounds were infected. In all cases, a positive effect of hyperbaric treatment was observed on the appearance of the wound, consisting in the reduction of purulent exudates in wound dressings.

Since the lack of consistency to continue the treatment is usually the reason for trophic ulcer recurrence, it is necessary to raise patients' awareness that hyperbaric therapy and skin graft eliminate the symptoms, and not the cause. Therefore, compression therapy, proper hygiene of the healed wound, protection against injury, as well as continued treatment of concomitant diseases, are essential $[6,16]$. Lower leg ulcers frequently affect elderly people, who often lead a solitary life, are neglected and require special care. Although the outpatient follow-up period was short in the presented study, each cured patient was reminded of the need for proper ulcer 
management. We believe that a proper combination therapy involving surgery and appropriate hyperbaric oxygenation is highly beneficial for patients with chronic trophic ulcers of the lower limbs.

\section{CONCLUSIONS}

1. Hyperbaric oxygen therapy is an effective treatment method for trophic ulcers of the lower limbs.

2. Combination therapy involving hyperbaric oxygen therapy and surgical treatment of trophic ulcers is a highly recommended method of treatment.

\section{REFERENCES}

1. Goldman MP, Weiss RA, Bergan JJ. Diagnosis and treatment of varicose veins; a review. J Am Acad Dermatol. 1994; 31: 393.

2. Junger M, Hahn V, Bort S. Significance of cutaneous microangiography for the pathogenesis of dermatitis in venous congestion due to chronic venous insufficiency Wien Med Wschr. 1994; 144: 206.

3. Polański J. Przewlekła niewydolność żylna w kończynach dolnych. Med po dypl. 1998; 7(2), 17-20 (in Polish).

4. Skillman JJ. Venous leg ulcer W. chronic problem wounds R. Rudolph, J.M. Little, Brown and Co. Boston 1983: 113.

5.Wojszwiłło-Geppert E, Włodarkiewicz A, Paliszewski J. Patogeneza owrzodzeń żylnych goleni. Przegląd Dermatologiczny 1997; 84: 271-277 (in Polish).

6. Goldman MP, Fronek A. Consensus paper on venous leg ulcer. J Dermatol Oncol. 1992; 18: 592.

7. Beele H, Naeyaert JM, Goeteyn M. Repeated cultured epidermal allograft in the treatment of chronic leg ulcer of various origins. Dermatologica 31: 183, 1991
8. Cornawall JV, Dore CJ, Levis JD. Leg ulcers; epidemiology and aetiology Br J Surg. 1986; 73: 693-696.

9. Franks PJ, Bosanquet N, Connolly M, Oldroyd MI, Moffatt CJ, Greenhalgh RM, McCollum CN. Venous ulcer healing; effect of socioeconomic factors in London. J Epidemiol. Community Health 49(4), 1995: 385-388.

10. De Plama RG, Kowallek DL. Venous ulceration: a cross-over study from nonoperative to operative treatment. J Vasc Surg. 24(5), 1996: 788-792.

11. Pierik EG, Wittens CH, Van urk H. Subfascial endoscopic ligation in the treatment of incompetent perforating veins. Eur J Endovasc Surg. 1995; 9(1): 38-41.

12. Dunn RM, Fuden GM, Walton RL. Free flap valvular transplantation for refractory venous ulceration. J Vasc Surg. 1994; 19: 525.

13. Amann-Vesti BR, Ruesch C, Gizelmann G, Hafner J, Koppensteiner R. Micro Angiography of swplint-skin grafts in venous ulcers. DermatolSurg. 2004, 30(3): 399-402.

14. Goodwin C, Heppenstall R. The effect of chronic hypoksia on wound healing. Advances in Experimental Med Biol. 1997; 94: 669-672.

15. Cornwall JV, Dore CJ, Lewis JD. Leg ulcers: epidemiology and etiology. Br J Surg. 1986; 73: 693-696.

16. Gourdin FW, Smith J. G. Jr. Ethiology of venous ulceration. South Med J. 1993; 86: 1142

17. Kawecki M, Sieroń A, Glik J, Nowak M, Szymańska B, Knefel G. Rola hiperbarii tlenowej w leczeniu chirurgicznym troficznych owrzodzeń podudzi spowodowanych przewlekłą niewydolnością żylną. Borgis Balneologia Polska 2006; 3: 150-155 (in Polish).

18. Kawecki M. i wsp. Terapia tlenem hiperbarycznym w centrum leczenia oparzeń. Doświadczenia własne. Balneologia Polska. 2006; 4 (in Polish).

19. Kawecki M. i wsp. Aktualne wskazania i możliwości zastosowania hiperbarycznej terapii tlenowej. Balneologia Polska. 2006; 4 (in Polish).

20. Deepika K, Myers RA, Cooley RA. Cardiovascular effects of hyperbaric oxygen in septic patients. Undersea Biomed Res. 1982; 9: 44.

21. Nylander G, Lewis D, Nordstrom H, Larson J. Reduction of postischemicedema with hyperbaric oxygen. PlastReconstrSurg. 1985; 76: 596-603.

22. Davidson JD, Mustoe TA. Oxygen in wound healing: more than a nutrient. Wound Repair Regen. 2001; 9: 175-177.

23. Mandell G. Bactericidal activity of aerobic and anaerobic polymorphonuclear neutrophils. Infect Immun. 1974; 9: 337-341. 